\title{
Selection for Grain Yield in Bread Wheat (Triticum aestivum L.) under Drought Stress
}

\section{M.S. Hassan}

Department of Agronomy, Faculty of Agriculture, South Valley University, Qena, Egypt.

\begin{abstract}
7 HE PRESENT study was carried out at the Experimental Farm of 1 the Agronomy Department, Faculty of Agriculture, South Valley University, Qena during the four growing seasons 2010/20112013/2014. Two cycles of pedigree selection for grain yield/plant were applied on a segregating population of bread wheat cross (Giza 168×SHORAWAKI BW-20313) in $\mathrm{F}_{3}$ and $\mathrm{F}_{4}$ generations under drought stress condition to estimate the response to selection. After the second cycle, the $\mathrm{F}_{5}$-selected families were evaluated under normal and drought environments. Results indicated that highly significant differences among $F_{3}$ and $F_{4}$ families for all studied characters, reflecting presence of sufficient amount of genetic variability. Moreover, obtained results showed that broad sense heritability estimates were moderately to high in $F_{3}, F_{4}$ and $F_{5}$ generations. Little differences were noticed between values of phenotypic and genotypic coefficients of variation. Pedigree selection for the two cycles led to improvement of grain yield/plant accompanied by favorable increase in the other studied characters. Drought resistance indices; stress susceptibility index (SSI), tolerance index (TOL) and stress tolerance index (STI) were estimated for grain yield/plant. Based on the values of SSI, STI and grain yield, the two selected families no. 8 and 15 considered the best selected families isolated from selection for grain yield/plant under drought stress condition.
\end{abstract}

Keywords: Bread wheat, Pedigree selection, Drought stress, Drought resistance indices, Grain yield.

Bread wheat (Triticum aestivum L.) is a stable food for more than one third of the world population and it is also the strategic cereal crop in Egypt. Due to continuous growing population in Egypt, the recent increase in local wheat production is not sufficient to cover the demands. Whereas, the annual local production is about 8.500 million metric tons in market year 2012/2013 and post forecasts in market year $2013 / 14$ to reach 8.7 million metric tons while, local consumption reached to 19.100 million metric tons in market year 2012/2013 and post forecasts at 17.7 million metric tons in market year 2013/14 (Anonymous, 2013). Moving to growing the desert may be contribute in narrowing this gab or solution the problem. But, in new reclaimed area, it is exposed throughout the growing seasons to different stresses such as drought, 
heat, salinity and low soil fertility causing reductions in crop yield (Ali \& AboEl-Wafa, 2006). Also according to limited of water resources in Egypt, in addition to current crises in relationships of Egypt and the Nil basin countries, especially Ethiopia, it became necessary to rationalize of irrigation water even in the ancient lands. Furthermore, over all the world drought is one of the prime a biotic stresses. Boyer (1982) and Passioura et al. (1993) reported that, drought stress at the vegetative phase causing leaf wilting, a decrease in plant height, number and area of leavesand delay in accuracy of buds and flowers. However, exposure to drought in the grain filling period drought stress reductions in grain yield (Ehdaie \& Shakiba, 1996). So, high yield and drought tolerance are the main objectives of most wheat breeding programs. Blum (1988) indicated to difficulty of breeding for drought tolerance by selecting solely for grain yield, because the lack of heritability of yield under drought stress conditions due to small genotypic variance or large genotype-environment interaction variance. On the other hand, pedigree selection method can be used to identify superior genotypes for grain yield in a cultivar development program. In addition, Mitra (2001) indicated to drought indices which provide a measure of drought based on yield loss under drought conditions in comparison to normal conditions-have been used for screening drought-tolerant genotypes.

Phenotypic and genotypic variance, heritability and genetic advance have been used to assess the magnitude of variance in wheat breeding material (Johnson et al., 1956; Zaheer et al., 1987 and Khan, 1990). In this connection, many researchers such as Golabadi et al. (2006), Shamroukh (2006); Ali (2011), Abd-El-Haleem et al. (2012) and Tharwat et al. (2013) mentioned that selection was effective in improving the grain yield under drought stress conditions.

Furthermore, pedigree selection method was effective to produce lines tolerant to drought stress (Tammam et al., 2004; Ali, 2011 and Abd-El-Haleem et al., 2012).

The present study was conducted to estimate the response to pedigree selection in early segregating generations of bread wheat population under drought stress.

\section{Materials and Methods}

The present study was conducted at the experimental farm of South Valley University, Qena, Egypt $\left(26^{\circ} 11^{\prime} \mathrm{N}\right.$ and $\left.32^{\circ} 44^{\prime} \mathrm{E}\right)$ during four growing seasons, 2010/2011-2013/2014. The population used in this study was originated from the cross between Giza 168×SHORAWAKI BW-20313. The pedigree and origin of the two parents are presented in Table 1. In the first season (Nov. 19 ${ }^{\text {th }}, 2010$ ), 500 plants from $\mathrm{F}_{2}$ generation were sown individually in two plots with nonreplicated plants. Each plot included 10 rows, $3 \mathrm{~m}$ long, $20 \mathrm{~cm}$ apart and $10 \mathrm{~cm}$ between hills (average 30 plants/row). Also, the parents were sown alongside each a row. The experiment did not receive any irrigation water after jointing stage (drought stress treatment). To determination percentage of soil moisture content, soil samples were regularly taken down to $30 \mathrm{~cm}$. depth after stopping of irrigation (Fig.1). Soil moisture content percentage was calculated on oven Egypt. J. Agron . 36, No.2 (2014) 
dry basis. Drought stress treatment was applied for all growing seasons. Some soil properties of the experimental site are shown in Table 2. The best 100 plants according to their phenotype were harvested. Data were collected on grain yield for each individual plant. The 50 highest grain yielding plants were selected to give $\mathrm{F}_{3}$-families. An equal number of grains from each plant (from the best 100 plants) were bulked to give $\mathrm{F}_{3}$ random bulk sample. In the second season, the 50 $\mathrm{F}_{3}$-families, parents and $\mathrm{F}_{3}$ bulk random sample were sown on Nov. $21^{\text {th }}$. Experimental layout was a randomized complete blocks design with three replications. Sowing was done on basis, each family, bulk sample and parent in single row, $3 \mathrm{~m}$ long $20 \mathrm{~cm}$ apart and $10 \mathrm{~cm}$ between hills in each replicate. Data were collected from ten guarded plants in each row and the means of these ten plants were subjected to statistical and genetic analysis. Data were recorded on plant height $(\mathrm{cm})(\mathrm{PH})$, spike length $(\mathrm{cm})(\mathrm{SL})$, number of spikelets/spike (no. spikelets), 100-grain weight (gm) (SI) and grain yield/plant (gm) (GY). Selection between and within families were practiced. The best plant in grain yield from each of the best 20 families was selected and saved to give the $F_{4}$ families.

TABLE 1. Pedigree of the two parental wheat genotypes.

\begin{tabular}{|l|c|l|}
\hline Genotypes & Pedigree & Origin \\
\hline $\mathrm{P}_{1}$ (Giza 168) & MRL/BUC//SERI & Egypt \\
\hline $\mathrm{P}_{2}$ & CM93046-8M-OY-OM-2Y-OB-OGZ & Mexico \\
\hline
\end{tabular}

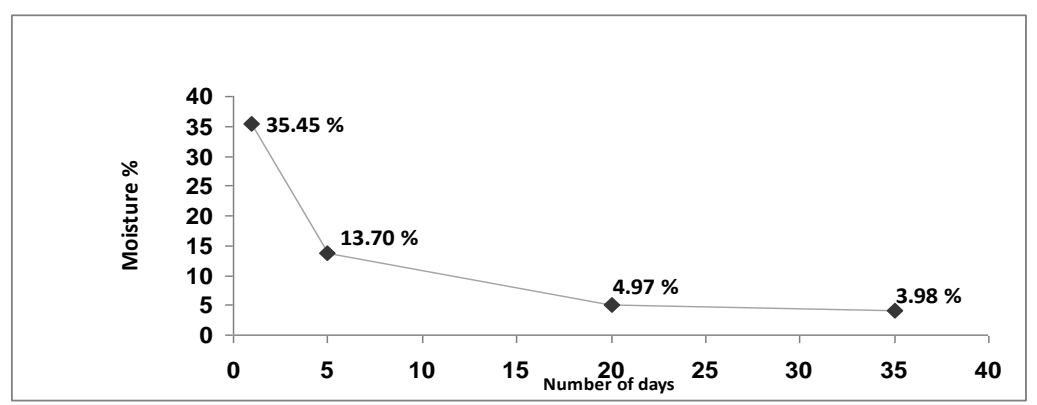

Fig. 1. Soil moisture content estimating from latest irrigation until harvest time (average all growing seasons).

In the third season, the 20 selected families, parents and $F_{4}$ bulk random sample were sown on Nov. $21^{\text {th }}$. The experimental design, number of replications, measured characters and pedigree selection were practiced as in the previous season. The best plant in grain yield from each of the best 8 families was selected and saved to give the $F_{5}$ families. In the fourth season, the 8 selected families, parents and $F_{5}$ bulk random sample were sown on Nov. $25^{\text {th }}$ in two field experiments. The first experiment was sown under irrigated conditions applied regularly as recommended (Normal treatment) while the other one did 
not receive any irrigation after jointing stage (Drought stress treatment) as in the previous seasons. The same experimental design and number of replications for the two experiments were the same as in the previous season, except long of each row was 2 meters (average 20 plants/row). A gain data were taken in the previous season. The cultural practices were applied for all the growing seasons as recommended. Weather data included maximum and minimum temperature and relative humidity measured in each season are shown in Table 3.

TABLE 2. Some physical and chemical properties of the experimental site (average all growing seasons).

\begin{tabular}{|c|c|c|c|c|c|c|c|c|c|c|c|c|c|c|}
\hline \multirow[b]{2}{*}{ 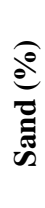 } & \multirow[b]{2}{*}{ 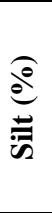 } & \multirow[b]{2}{*}{$\underbrace{\frac{\partial}{0}}_{\frac{3}{0}}$} & \multirow{2}{*}{ 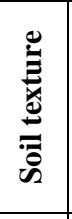 } & \multirow[b]{2}{*}{ 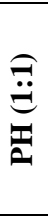 } & \multirow{2}{*}{ 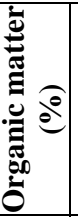 } & \multirow{2}{*}{ 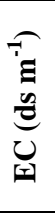 } & \multirow{2}{*}{ 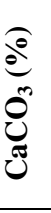 } & \multicolumn{7}{|c|}{ Soluble ions $\left(\mathrm{mmol} \mathrm{L}^{-1}\right)$} \\
\hline & & & & & & & & $\stackrel{+}{\tilde{Z}}$ & $\stackrel{+}{*}$ & 每 & ${ }^{\ddagger}{ }^{\ddagger}$ & \begin{tabular}{l}
$e^{m}$ \\
\hdashline \\
\end{tabular} & $\overline{0}$ & $i_{\mathscr{N}}^{+}$ \\
\hline 용 & $\stackrel{\oplus}{\sim}$ & $\simeq$ & 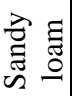 & $\stackrel{n}{n}$ & $\stackrel{n}{0}$ & $\stackrel{n}{a}$ & $\stackrel{\infty}{\leftrightarrow}$ & $\stackrel{n}{n}$ & $\stackrel{\infty}{\infty}$ & $\stackrel{n}{\beth}$ & $\stackrel{\cong}{\Xi}$ & $\begin{array}{l}8 \\
\stackrel{\text { ¿े }}{ }\end{array}$ & $\begin{array}{l}\stackrel{0}{n} \\
\text { त }\end{array}$ & 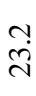 \\
\hline
\end{tabular}

\section{Statistical analysis}

Analysis of variance with randomized complete block design was carried out according to Snedecor \& Cochran (1980). Differences between means were tested by the revised LSD according to El-Rawi \& Khalafalla (1980) on the basis of analysis of variance for all genotypes $\left(\mathrm{F}_{5}\right.$-selected families, parents and sample bulk). Estimates of phenotypic and genotypic coefficients of variation (PCV and GCV) were calculated according to Singh \& Chaudhary (1985). Broad sense heritability (BSH) was estimated as the ratio of genotypic to phenotypic variance according to Falconer (1989). Realized response to selection were calculated as the deviation percentage of the overall mean from the best parent and bulk sample according to Falconer (1989). Drought resistance indices were calculated using the following equations:

- $\quad$ Stress Susceptibility Index $(\mathrm{SSI})=\frac{1-(\mathrm{Ys} / \mathrm{Yp})}{1-(\overline{\mathrm{Y}} \mathrm{s} / \overline{\mathrm{Y}} \mathrm{p})}($ Fischer $\&$ Maurer, 1978)

- $\quad$ Tolerance Index $(\mathrm{TOL})=\mathrm{Y}_{\mathrm{p}}-\mathrm{Y}_{\mathrm{s}}($ Hossain et al., 1990).

- $\quad$ Stress Tolerance Index $(\mathrm{STI})=\left(\mathrm{Y}_{\mathrm{p}}+\mathrm{Y}_{\mathrm{s}}\right) / \overline{\mathrm{Y}}_{\mathrm{p}}^{2} \quad($ Fernandez, 1992).

where: $\mathrm{Y}_{\mathrm{s}}=$ The yield in drought stress environment.

$\mathrm{Y}_{\mathrm{p}}=$ The yield in normal environment.

$\overline{\mathrm{Y}}_{\mathrm{s}}=$ Total yield mean in drought stress environment.

$\overline{\mathrm{Y}}_{\mathrm{p}}=$ Total yield mean in normal environment. 
SELECTION FOR GRAIN YIELD ...

\begin{tabular}{|c|c|c|c|c|c|c|c|c|c|}
\hline \multirow{8}{*}{ 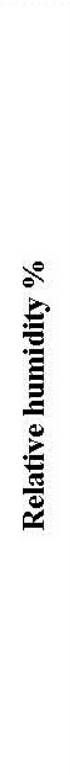 } & \multirow{2}{*}{ 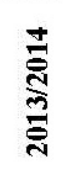 } & $\dot{\Xi}$ & $\stackrel{\circ}{\underset{\sim}{\sim}}$ & חัे & $\tilde{\omega}$ & $\vec{\Xi}$ & $\stackrel{+}{ \pm}$ & $\stackrel{+}{\stackrel{\longrightarrow}{r}}$ & $\stackrel{\infty}{\sim}$ \\
\hline & & $\stackrel{\dot{J}}{\Sigma}$ & $\begin{array}{l}0 \\
\frac{0}{0}\end{array}$ & $\ddot{n}$ & $\begin{array}{c}a \\
\infty\end{array}$ & $\underset{m}{m}$ & $\ddot{n}$ & $\stackrel{m}{m}$ & $\begin{array}{l}0 \\
\stackrel{\infty}{\infty}\end{array}$ \\
\hline & \multirow{2}{*}{ 곡 } & $\dot{E}$ & nे & $\begin{array}{l}n \\
\infty \\
\infty\end{array}$ & तु่ & $\stackrel{\circ}{\circ}$ & $\stackrel{9}{=}$ & $\underset{\infty}{\infty}$ & $\stackrel{m}{r}$ \\
\hline & & 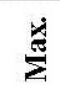 & $\underset{⿱ 亠 凶}{\stackrel{\Delta}{n}}$ & $\vec{\nabla}$ & $\begin{array}{l}n \\
\text { fo }\end{array}$ & $\stackrel{m}{\tilde{n}}$ & $\ddot{v}$ & m. & $\stackrel{m}{\stackrel{2}{a}}$ \\
\hline & \multirow{2}{*}{ 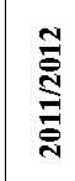 } & $\dot{E}$ & $\begin{array}{l}00 \\
\ddot{y}\end{array}$ & ণ্ & $\underset{\text { mे }}{\stackrel{N}{d}}$ & $\stackrel{\overbrace{}}{\infty}$ & $\begin{array}{l}\infty \\
\stackrel{\sim}{\sim}\end{array}$ & $\ddot{0}$ & $\stackrel{\circ}{\sim}$ \\
\hline & & 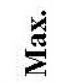 & 후 & $\stackrel{\rho}{\circ}$ & 형 & in & $\frac{\vec{n}}{\vec{n}}$ & $\frac{\sim}{m}$ & 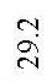 \\
\hline & \multirow{2}{*}{ 콩 } & $\dot{E}$ & $\begin{array}{l}n \\
\infty \\
\infty\end{array}$ & ָુ & ì & $\stackrel{\infty}{\sim}$ & $\overrightarrow{\mathrm{I}}$ & $=$ & $\stackrel{m}{\infty}$ \\
\hline & & $\stackrel{\dot{E}}{\mathrm{E}}$ & $\stackrel{n}{8}$ & ָુ & $\begin{array}{l}\infty \\
\stackrel{\infty}{\infty}\end{array}$ & $\underset{i n}{\stackrel{1}{n}}$ & $\underset{\mathcal{G}}{\mathcal{G}}$ & 户্ল & $\stackrel{n}{\stackrel{n}{2}}$ \\
\hline \multirow{8}{*}{ 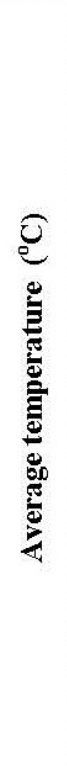 } & \multirow{2}{*}{$\begin{array}{l}\stackrel{ \pm}{\vec{N}} \\
\stackrel{\text { ले }}{\bar{N}}\end{array}$} & $\dot{E}$ & $\exists$ & $\underset{\infty}{\infty}$ & $\stackrel{\infty}{\infty}_{\infty}^{\circ}$ & $\stackrel{\check{\rho}}{\circ}$ & $\overrightarrow{\breve{a}}$ & $\overrightarrow{\mathrm{N}}$ & $\overrightarrow{\tilde{n}}$ \\
\hline & & 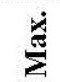 & $\underset{\sim}{\sim}$ & $\underset{\sim}{\vec{d}}$ & $\begin{array}{l}\infty \\
\stackrel{\lambda}{j}\end{array}$ & $\vec{d}$ & iे & $\ddot{m}$ & 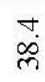 \\
\hline & \multirow{2}{*}{ 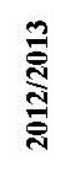 } & $\dot{B}$ & $\stackrel{m}{\text { m. }}$ & $\stackrel{\infty}{\circ}$ & $\cong$ & $=$ & $\stackrel{\sim}{\mathscr{n}}$ & $\vec{E}$ & $\stackrel{\infty}{\stackrel{\lambda}{j}}$ \\
\hline & & $\stackrel{\dot{m}}{\tilde{E}}$ & $\begin{array}{l}0 \\
\stackrel{+}{\circ}\end{array}$ & $\vec{d}$ & $\stackrel{\tilde{N}}{ }$ & $\begin{array}{l}n \\
\stackrel{\sim}{\sim}\end{array}$ & ल & $\stackrel{m}{m}$ & $\overrightarrow{\mathrm{m}}$ \\
\hline & \multirow{2}{*}{ 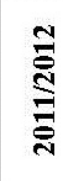 } & $\dot{E}$ & $\stackrel{\infty}{=}$ & $\stackrel{\infty}{\sim}$ & $\stackrel{\infty}{i} \underset{i}{n}$ & $\stackrel{-}{9}$ & $\stackrel{\infty}{=}$ & $\begin{array}{l}\infty \\
\stackrel{\infty}{\infty}\end{array}$ & $\underset{\sim}{\vec{\lambda}}$ \\
\hline & & $\stackrel{i}{i}$ & $\ddot{i}$ & 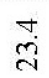 & $\stackrel{i}{8}$ & $\stackrel{\infty}{\stackrel{\sim}{\sim}}$ & $\vec{\Delta}$ & 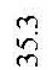 & $\underset{\infty}{\infty}$ \\
\hline & \multirow{2}{*}{ 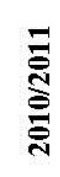 } & $\dot{E}$ & $\stackrel{+}{I}$ & $\stackrel{\text { İ }}{\varrho}$ & $\underset{\infty}{\infty}$ & $\stackrel{9}{=}$ & $\stackrel{m}{-}$ & $\stackrel{n}{=}$ & 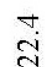 \\
\hline & & d & $I$ & $\stackrel{9}{+}$ & 9 & $\stackrel{\infty}{\infty}$ & $\stackrel{m}{\infty}$ & ¿ & $\stackrel{Y}{N}$ \\
\hline & & & 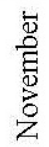 & 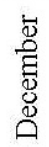 & $\begin{array}{l}\text { 氖 } \\
\text { 吾 }\end{array}$ & 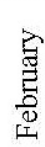 & 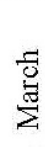 & 宽 & 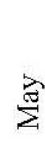 \\
\hline
\end{tabular}

Egypt. J. Agron . 36, No. 2 (2014) 


\section{Results and Discussion}

Base population

Results of analysis of variance revealed highly significant differences among selected families for all studied characters (Table 4). These results reflect the presence of genetic variability among selected families in these studied characters. The data presented in Table 4 showed the performance of selected families as average which were $79.41 \mathrm{~cm}, 12.23 \mathrm{~cm}, 20.23$ spikelets, $3.06 \mathrm{gm}$ and $2.98 \mathrm{gm}$ for plant height, spike length, number of spikelets/spike, 100-grain weight and grain weight, respectively.

TABLE 4. Mean squares, means, phenotypic \& genotypic coefficients of variability and heritability for all the studied characters of $F_{3}$ selected families (base population) under drought conditions.

\begin{tabular}{|l|c|c|c|c|c|c|}
\hline \multirow{2}{*}{$\begin{array}{l}\text { Source of } \\
\text { variation }\end{array}$} & \multirow{2}{*}{$\begin{array}{c}\text { Degrees } \\
\text { of } \\
\text { freedom }\end{array}$} & $\begin{array}{c}\text { Characters } \\
\text { Plant } \\
\text { height } \\
(\mathbf{c m})\end{array}$ & $\begin{array}{c}\text { Spike } \\
\text { length } \\
(\mathbf{c m})\end{array}$ & $\begin{array}{c}\text { No. of } \\
\text { spikelets } \\
\text { /spike }\end{array}$ & $\begin{array}{c}\text { 100-grain } \\
\text { weight } \\
\text { (gm) }\end{array}$ & $\begin{array}{c}\text { Grain } \\
\text { yield/plant } \\
\text { (gm) }\end{array}$ \\
\hline Reps. & 2 & 27.05 & 0.03 & 0.81 & 0.06 & 0.02 \\
\hline $\begin{array}{l}\text { Selected } \\
\text { families }\end{array}$ & 49 & $320.99 * *$ & $4.49 * *$ & $6.45^{* *}$ & $1.36 * *$ & $4.37 * *$ \\
\hline Error & 98 & 8.97 & 0.28 & 0.66 & 0.10 & 0.15 \\
\hline $\begin{array}{l}\text { Mean (F } \\
\text { families) }\end{array}$ & 79.41 & 12.23 & 20.23 & 3.06 & 2.98 \\
\hline Best parent & & 81.50 & 12 & 20 & 3.37 & 3.28 \\
\hline Bulk sample & 69 & 14.40 & 21 & 2.88 & 2.55 \\
\hline PCV & 13.39 & 10.60 & 7.96 & 23.57 & 41.91 \\
\hline GCV & 12.84 & 9.67 & 6.87 & 21.18 & 39.85 \\
\hline BSH \% & 92.05 & 83.33 & 74.52 & 80.77 & 90.38 \\
\hline
\end{tabular}

$* *=$ Significant at 0.01 probability level

$\mathrm{PCV}=$ Phenotypic coefficients of variation

$\mathrm{GCV}=$ Genotypic coefficients of variation

$\mathrm{BSH}=$ Broad sense heritability

Phenotypic and genotypic coefficients of variability (PCV and GCV) and broad sense heritability are presented in Table 4 . The values of PCV and GCV were (41.91 and $39.85 \%)$ for grain yield/plant. Thus, sufficient amount of genetic variability in grain yield/plant among the selected families for further improvement was noticed from the significant differences among families and estimated values of both PCV and GCV. Moreover, little difference was observed between PCV and GCV values, indicating the importance of genetic effects in the inheritance of grain yield/plant. High estimates of heritability in broad sense ranged from $74.52 \%$ (number of spikelets/spike) to $92.05 \%$ (plant height) were obtained. Burton (1952) reported that genotypic coefficient of variation together with heritability estimate would seem to give the best picture of the amount of the genetic advance from selection. In contrast, Abdel-Haleem (2003), El-Sayed (2006), Memon et al. (2007) and El-Sayed (2012) found that decreasing in genetic variance magnitude and heritability under stress conditions.

Egypt. J. Agron . 36, No.2 (2014) 
However, high values of heritability in broad sense for days to flowering, plant height, 1000-grain weight and grain yield were obtained by Kheiralla et al. (2001) and Shamroukh (2006). The obtained results from this study are in agreement with those of Ali (2011).

\section{Pedigree selection cycles}

The $1^{\text {st }}$ cycle

After first cycle of selection for grain yield/plant, there were highly significant differences among selected families for all studied characters (Table 5). Also, results presented in Table 5 showed that phenotypic and genotypic coefficients of variability and broad sense heritability for all studied characters. It is clear from the obtained results presence of sufficient amount of variability for improvement. Moreover, as it is observed in $\mathrm{F}_{3}$ generation, little difference was found between PCV and GCV values, for grain yield/plant, indicating the importance of genetic effects in the inheritance of this character. These results are in the line with those obtained by Abdel-Haleem (2012).

TABLE 5. Mean squares, means, phenotypic \& genotypic coefficients of variability and heritability for all the studied characters of $F_{4}$ selected families under drought conditions.

\begin{tabular}{|l|c|c|c|c|c|c|}
\hline \multirow{2}{*}{$\begin{array}{l}\text { Source of } \\
\text { variation }\end{array}$} & $\begin{array}{c}\text { Degrees } \\
\text { of } \\
\text { freedom }\end{array}$ & $\begin{array}{c}\text { Plant } \\
\text { height } \\
\text { (cm) }\end{array}$ & $\begin{array}{c}\text { Spike } \\
\text { length } \\
\text { (cm) }\end{array}$ & $\begin{array}{c}\text { No. of } \\
\text { spikelets/ } \\
\text { spike }\end{array}$ & $\begin{array}{c}\text { 100-grain } \\
\text { weight } \\
\text { (gm) }\end{array}$ & $\begin{array}{c}\text { Grain } \\
\text { yield/plant } \\
\text { (gm) }\end{array}$ \\
\hline Reps. & 2 & 4.55 & 0.06 & 3.02 & 0.10 & 0.03 \\
\hline $\begin{array}{l}\text { Selected } \\
\text { families }\end{array}$ & 19 & $315.40^{* *}$ & $4.63 * *$ & $13.23 * *$ & $1.40 * *$ & $3.82^{* *}$ \\
\hline Error & 38 & 26.29 & 0.19 & 0.96 & 0.11 & 0.15 \\
\hline $\begin{array}{l}\text { Mean (F } \text { selected } \\
\text { families) }\end{array}$ & 78.35 & 12.10 & 20.30 & 3.09 & 3.48 \\
\hline Best parent & 80 & 11.80 & 21 & 3.24 & 3.22 \\
\hline Bulk sample & 69.50 & 13 & 22 & 2.46 & 2.72 \\
\hline PCV & 14.14 & 10.68 & 11.07 & 23.78 & 33.63 \\
\hline GCV & 12.53 & 10.05 & 9.96 & 21.22 & 31.74 \\
\hline BSH \% & 78.57 & 88.62 & 80.99 & 79.63 & 89.05 \\
\hline
\end{tabular}

$* *=$ Significant at 0.01 probability level

$\mathrm{PCV}=$ Phenotypic coefficients of variation

$\mathrm{GCV}=$ Genotypic coefficients of variation

$\mathrm{BSH}=$ Broad sense heritability 
The $2^{\text {nd }}$ cycle

After two cycles of selection for grain yield, highly significant differences were observed among selected families for all studied characters (Table 6). Moreover, values of PCV, GCV and heritability are presented in Table 6. Although, decreasing values of PCV and GCV after two cycles of selection for grain yield, it could be mentioned that some of genetic variability were remained. But it is clear that magnitude of genotypic variability under drought stress environment were lower than those observed under normal environment for all studied characters. In addition, values of broad sense heritability of all studied characters except for spike length under drought stress environment were lower than those obtained under normal environment.

TABLE 6. Mean squares, means, phenotypic \& genotypic coefficients of variability and heritability for all the studied characters of $F_{5}$ selected families under normal and drought stress environments.

\begin{tabular}{|c|c|c|c|c|c|c|c|c|c|c|c|}
\hline \multirow[b]{3}{*}{$\begin{array}{l}\text { Source of } \\
\text { variation }\end{array}$} & \multirow[b]{3}{*}{$\begin{array}{c}\text { Degrees } \\
\text { of } \\
\text { freedom }\end{array}$} & \multicolumn{10}{|c|}{ Characters } \\
\hline & & \multicolumn{5}{|c|}{ Normal environment } & \multicolumn{5}{|c|}{ Drought stress environment } \\
\hline & & 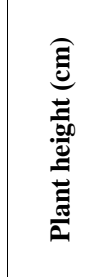 & 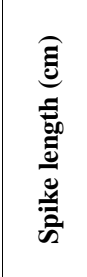 & 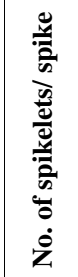 & 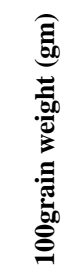 & 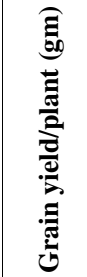 & 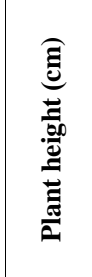 & 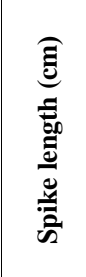 & 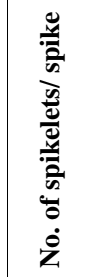 & 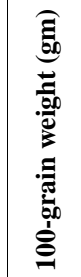 & 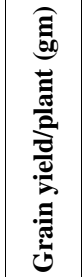 \\
\hline Reps. & 2 & 34.39 & 0.20 & 0.38 & 0.37 & 0.82 & 3.78 & 0.05 & 0.88 & 0.09 & 0.28 \\
\hline $\begin{array}{l}\text { Selected } \\
\text { families }\end{array}$ & 7 & $265.06 * *$ & $9.01 * *$ & $8.10 * *$ & $2.13 * *$ & $2.80 * *$ & $67.68 * *$ & $7.03 * *$ & $7.21 * *$ & $1.19 * *$ & $1.22 * *$ \\
\hline Error & 14 & 15.95 & 0.27 & 0.47 & 0.22 & 0.24 & 5.61 & 0.19 & 0.73 & 0.13 & 0.35 \\
\hline \multicolumn{2}{|c|}{$\begin{array}{l}\text { Mean } \\
\left(\mathrm{F}_{5} \text { selected families }\right)\end{array}$} & 85.31 & 12.95 & 22 & 5.62 & 6.65 & 80.73 & 12.77 & 21.25 & 4.22 & 5.49 \\
\hline \multicolumn{2}{|l|}{ Best parent } & 84.78 & 12.16 & 20 & 4.05 & 4.46 & 78.90 & 10.47 & 20 & 3.17 & 3.39 \\
\hline \multicolumn{2}{|c|}{ Bulk sample } & 70.17 & 12.22 & 20 & 4.63 & 5.14 & 68.40 & 11.97 & 19 & 2.74 & 2.98 \\
\hline \multicolumn{2}{|l|}{ PCV } & 11.66 & 13.75 & 7.86 & 16.55 & 15.64 & 6.35 & 12.29 & 8.00 & 16.35 & 13.30 \\
\hline \multicolumn{2}{|l|}{ GCV } & 10.68 & 13.20 & 7.23 & 14.23 & 13.83 & 5.64 & 11.82 & 6.92 & 13.98 & 10.56 \\
\hline \multicolumn{2}{|l|}{ BSH \% } & 83.89 & 91.51 & 84.39 & 74.42 & 77.98 & 78.67 & 92.31 & 74.74 & 72.92 & 64.15 \\
\hline
\end{tabular}

$* *=$ Significant at 0.01 probability level, $\mathrm{PCV}=$ Phenotypic coefficients of variation, GCV= Genotypic coefficients of variation, $\mathrm{BSH}=$ Broad sense heritability

In this concern, Abd-El-Haleem et al. (2012) indicated that drought stress conditions accompanied by lower broad sense heritability. On the other hand, the highest means of selected families for all studied characters were resulted under

Egypt. J. Agron . 36, No.2 (2014) 
normal environment compared to the other. This decrease may be due to the lack of water under drought stress conditions. These results are agreement with those obtained by Mahamoud (2007).

\section{Realized gains to selection}

The realized responses to selected in grain yield and the correlated characters after two cycles of pedigree selection under two evaluation environments are shown in Table 7 . The result indicated that selection caused increasing in all studied characters. Increasing in all studied characters realized by selection are observed under the two evaluation environments. Realized response to selection was obtained for grain yield by (49.10 and $29.38 \%)$ and (61.95 and $84.23 \%$ ) from the best parent and bulk sample at normal and drought stress environment, respectively. These results indicated that pedigree selection led to improvement of grain yield under drought stress condition, indicating the role of additive gene action for inheritance of this character. From the obtained results, it is clear that the highest gains were realized for grain yield when selections were evaluated at drought stress environment compared to the other. Moreover, favorable increase in the other studied characters over the best parent and bulk sample accompanied pedigree selection for grain yield/plant. In this concern, Ali (2011) found that favorable increase in plant height over bulk sample accompanied pedigree selection for grain yield/plant under drought stress conditions. In addition, favorable increase in 1000-grain weight accompanied pedigree selection for grain yield/plant under drought stress conditions was concluded by Abd-ElHaleem et al. (2012). In contrary, unfavorable performance in 1000-grain weight accompanied pedigree selection for grain yield/plant under drought stress conditions was obtained by Benmoussa \& Achouch (2005), Shamroukh (2006), El-Morshidy et al. (2010) and Ali (2011).

TABLE 7. Realized gains and correlated responses to two cycles of pedigree selection for grain yield under drought stress conditions measured in percentage from the best parent and bulk sample.

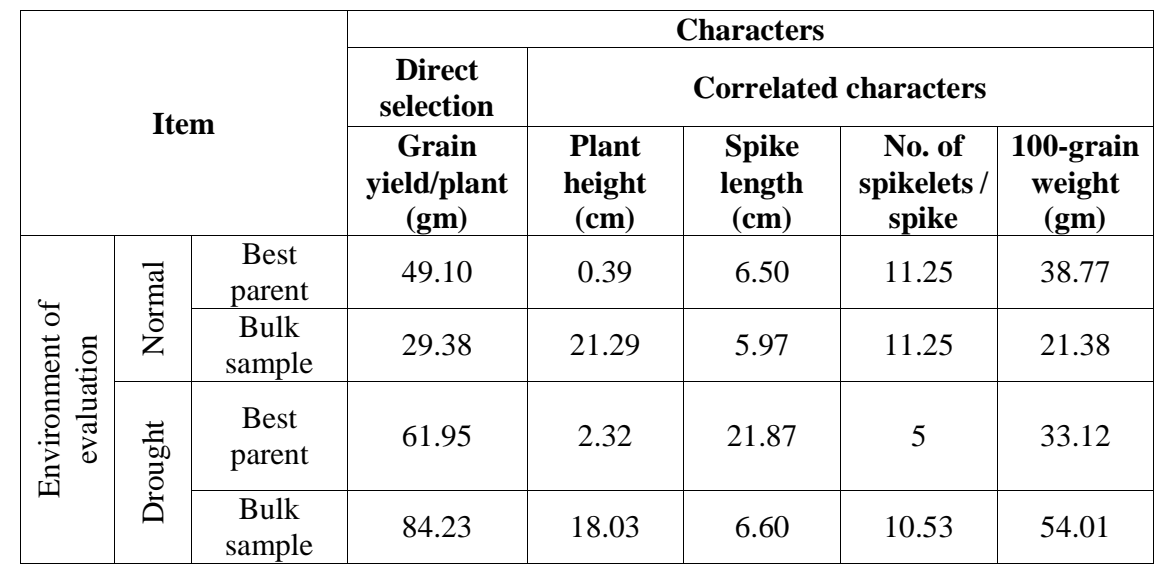


Means of the superior selections

Means of the eight selected families after two cycles of pedigree selection for grain yield/plant which evaluated under normal and drought stress environments are presented in Table 8 . From the obtained results, it is clear that all selected families exceeded their parents and the bulk sample in yielding ability under the two evaluation environments. Also, it is clear that, improvement of yielding performance of all the selected families when grown at favorable condition compared to unfavorable.

The superior family no. 12 had the highest grain yield (8.12 and $6.33 \mathrm{gm})$ under normal and drought stress environments, respectively. However, the second and third families in yield rank, under drought stress condition, no. 8 and 46 (6.11 and $5.98 \mathrm{gm})$ became the third and the second ranking (7.50 and 7.37 gm) when they evaluated under normal environment. Thus, it could be concluded that the families' no. 12,8 and 46 performed well under both environments. In contract, family no. 23 came in the latest ranking under normal environment by $5.32 \mathrm{gm}$ and almost it had the same trend by $4.74 \mathrm{gm}$ when it evaluated under drought stress condition. With respect to family no. 20, it was the latest in yield rank (4.62 gm) under drought stress condition, but it performed well when it evaluated under normal condition $(6.61 \mathrm{gm})$. Concerning the other studied characters, it is clear that selected families had well performance with different trends in ranking under both environments. These results indicated that effectiveness of pedigree selection to improve yielding ability under drought stress condition. The obtained results are in agreement with those obtained by Ali (2011), Abd-El-Haleem et al. (2012) and El-Sayed (2012).

\section{Drought resistance indices}

Resistance indices were calculated on the basis of grain yield of genotypes (selected families, parents and bulk sample) are presented in Table 8. According to the SSI, records showed that families no. 1, 6, 23, 15 and 8 were the least susceptibility. Based on the TOL, values showed that families no. 1, 23 and 6 had the most tolerance. Whereas, they had the lowest TOL values, indicating, smaller yield reduction when grown under stress conditions. By another view, it could be say, the selected families by well performance under drought stress condition, then had greater TOL values will give larger yield when grown at favorable condition. Therefore, it could be decided that these selected families considered good families under both environments. From STI values, it can be concluded that families no. 12, 8, 46 and 15 were the most tolerance families: in contrast the parents and bulk sample showed high sensitivity. From the obtained results, it is clear that the two selected families no. 8 and 15 had lower values than one of SSI with high values of STI and grain yield. Therefore, it could be considered these two families are the best selected families obtained from pedigree selection for grain yield/plant under drought stress condition. In this concern, Ali (2011) reported that, four selected families under normal and drought environments and over them were low values than one of DSI with highest grain yield.

Egypt. J. Agron . 36, No.2 (2014) 


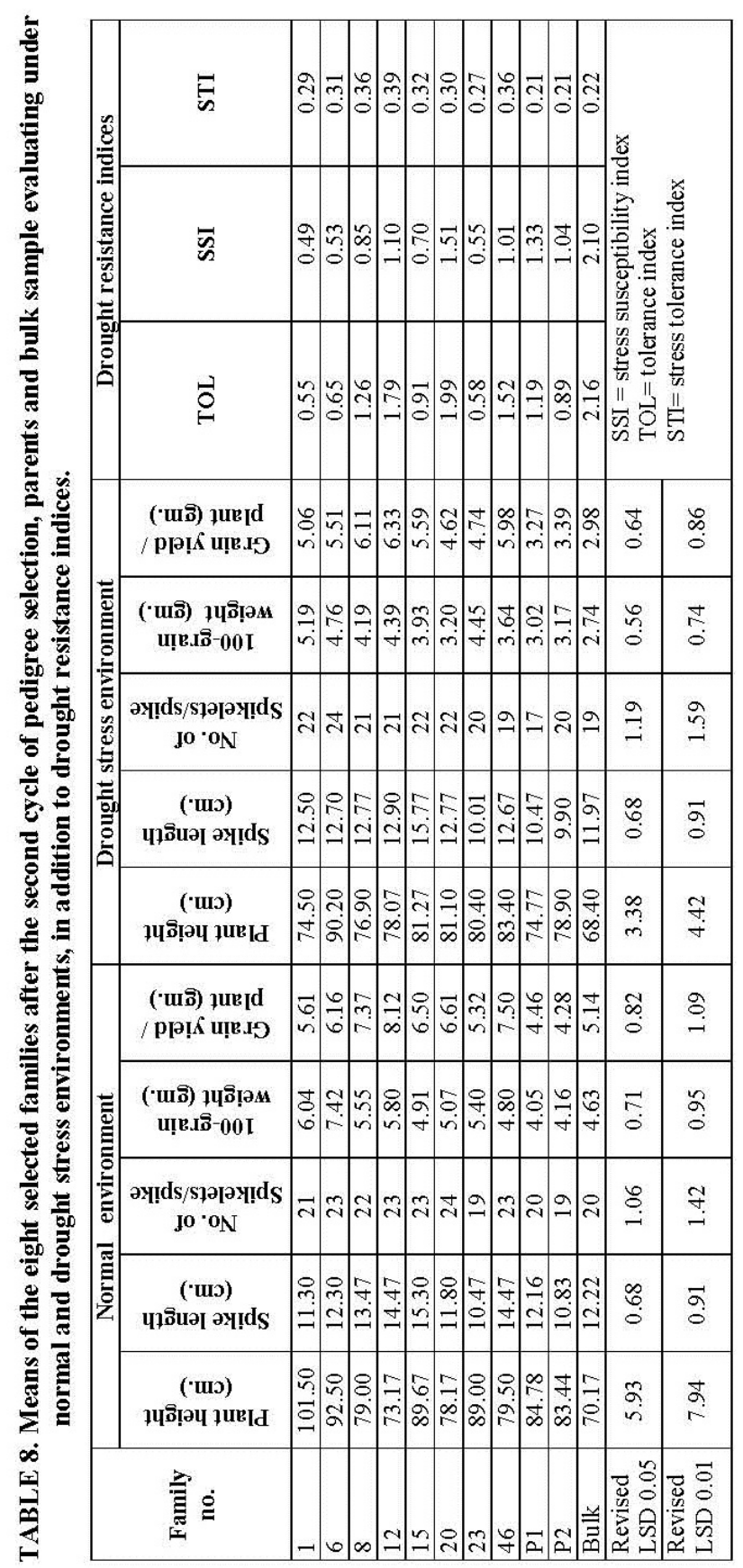

Egypt. J. Agron . 36, No. 2 (2014) 


\section{Conclusion}

Finally, it is be concluded that two cycles of pedigree selection for grain yield/plant under drought stress condition were effective in improvement yielding ability and resulting well families. Similar improvement was observed in most of the other studied characters.

\section{References}

Abd-El-Haleem, S.H.M. (2003) The performance, stability and genetic analysis for agronomic traits in bread wheat under drought condition. Ph.D. Thesis, Fac. of Agric., Assiut Univ., Egypt.

Abd-El-Haleem, S.H.M., Mohamed, S.M.S. and Metwali, E.M.R. (2012) Efficiency of pedigree selection in bread wheat under drought conditions. II-Yield and its components traits. Life Science Journal, 9 (4), 3430-3437.

Ali, M.A. (2011) Pedigree selection for grain yield in spring wheat (Triticum aestivum L.) under drought stress conditions. Asian Journal of Crop Science, 3, 158-168.

Ali, M.A. and Abo-El-Wafa, A.M. (2006) Inheritance and selection for earliness in spring wheat under heat stress. Assiut J. Agric. Sci. 37,77-94.

Anonymous (2013) USDA Foreign Agricultural Service, Global Agricultural Information Network (GAIN Report). http://gain. fas.usda. gov/ Recent\%20 GAIN\%20 Publications/ Grain\% 20 and \%20Feed\% 20Annual_Cairo_Egypt_4-4-2013.pdf.

Benmoussa, M. and Achouch, (2005) Effect of water stress on yield and its components of some cereals in Algeria. J. Cent. Eur. Agric. 6, 427-434.

Blum, A. (1988) "Plant Breeding for Stress Environments". CRC Press Inc., Boca Raton, USA, ISBN-10, 0849363888.

Boyer, J.S. (1982) Plant productivity and environment. Science, 218, 443-448.

Burton, G.W. (1952) Quantitative inheritance in grasses. Proc. $6^{\text {th }}$ Int. Grassland Congr., 1, pp. 277-283.

Ehdaie, B. and Shakiba, M.R. (1996) Relationship of internode-specific weight and water-soluble carbohydrates in wheat. Cereal Res. Commun, 24, 61-67.

El-Morshidy, M.A., Kheiralla, K.A., Ali, M.A. and Ahmed, A.A.S. (2010) Efficiency of pedigree selection for earliness and grain yield in two wheat populations under water stress conditions. Assiut J. Agric. Sci. 37, 77-94.

El-Rawi, K. and Khalafalla, A.M. (1980) "Design and Analysis of Agricultural Experiments". El-Mousel University, Iraq, pp. 19.

El-Sayed, A.G.A. (2006) Genetical studies on some bread wheat crosses under heat stress. M.Sc. Thesis, Fac. of Agric, Minia Univ., Egypt.

Egypt. J. Agron . 36, No.2 (2014) 
El-Sayed, A.G.A. (2012) Comparison of three selection methods to improve yield and its components in two bread wheat populations under heat stress conditions. Ph.D. Thesis, Fac. of Agric., Al-Azhar Univ., Egypt.

Falconers, D.S. (1989) “Introduction to Quantitative Genetics". (3 ${ }^{\text {rd }}$ ed.) Longman Scientific and Technical, Longman House, Burnt Mill, Harlow, Essex, England.

Fernandez, G.C.J. (1992) Effective selection criteria for assessing stress tolerance. In: Proceedings of the International Symposium on Adaptation of Vegetables and Other Food Crops in Temperature and Water Stress. Kuo C.G. (Ed.). Publication, Tainan, Taiwan.

Fischer, R.A. and Maurer, R. (1978) Drought resistance in spring wheat cultivars. IGrain yield response. Aust. J. Agric. Res. 29, 897-907.

Golabadi, M. Arzani, A. and Maibody, S.A.M.M. (2006) Assessment of drought tolerance in segregating populations in durum wheat. Afr. Agric. J. Res. 1(1), 162-71.

Hossain, A.B.S., Sears, A.G., Cox, T.S. and Paulsen, G.M. (1990) Desiccation tolerance and its relationship to assimilate partitioning in winter wheat. Crop Sci. 30, 622-627.

Johnson, H.W., Robinson, H.F. and Comstock, R.E. (1956) Estimation of genetic and environment variability in soybean. Agron. J. 47, 314-318.

Khan, N.I. (1990) Variability and character association in wheat. J. Agric. Res. 28, 193200.

Kheiralla, K.A., El-Morshidy, M.A. and Zakaria, M.M. (2001) Inheritance of earliness and yield in bread wheat under favorable and late sowing dates. Proceedings of the $2^{\text {nd }}$ Plant Breeding Conference, $2^{\text {nd }}$ Oct., Assiut University, Egypt, pp. 219-240.

Mahmoud, A. M. (2007) Late and early pedigree selection for grain yield with different selection criteria under two water treatments in wheat (Triticum aestivum L.). Egypt. J. Plant Breed. 11 (2), 611-625.

Memon, S., Qureshi, M., Ansary, B.A. and Sial, M.A. (2007) Genetic heritability for grain yield and its related characters in spring wheat (Triticum aestivum L.). Pak. J. Bot. 39 (5), 1503-1509.

Mitra, J. (2001) Genetics and genetic improvement of drought resistance in crop plants. Curr. Sc. 80, 758-762.

Passioura, J.B., Condon, A.G. and Richards, R.A. (1993) Water deficits, the development of leaf area and crop productivity. In: "Water Deficits Plant Responses from Cell to Community”. Smith J.A.C., Griffiths H. (Ed.). pp. 253-264. BIOS Scientific Publishers Limited, Oxford.

Shamroukh, M. (2006) Breeding for drought tolerance in bread wheat under new land condition in Upper Egypt. Ph.D. Thesis, Minia University, Egypt. 
Singh, R.K. and Chaudhary, B.D. (1985) "Biometrical Methods in Quantitative Analysis". Kalayanic Publishers. New Delhi.

Snedecor, G.W. and Cochran, W.G. (1980) "Statistical Methods". $7^{\text {th }}$ ed., pp.507. Iowa State University Press, Iowa, USA., ISBN-10:0-81381560-6,

Tammam, A.A.M., El-Ashmoony, M.S.F., El-Sherbeny, A.A. and Amin, L.A.A. (2004) Selection responses for drought tolerance in two bread wheat crosses. Egypt. J. Agric. Res. 82, 1213-1226.

Tharawat El Ameen, Akbar Hossain and Jaime A. Teixeira da Silva, (2013) Genetic analysis and selection for bread wheat (Triticum aestivum L.) yield and agronomic traits under drought conditions. Int. J. Plant Breeding, 7 (1), 61-68.

Zaheer, A., Chaudhary, A. R. and Shakoor, M.S. (1987) Path coefficient analysis of wheat yield components. J. Agric. Res. 25, 303-309.

(Received 14/8/2014; accepted $7 / 9 / 2014)$ 


\section{الانتخاب لمحصول الحبوب فى قمح الخبز تحت ظروف الجفاف}

قسم المحاصيل سيد حسن كلية الزر اعة ـ جامعة جنوب الو ادى ـ قنا ـ مصر .

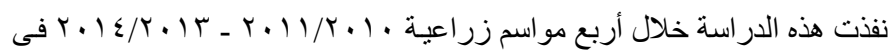

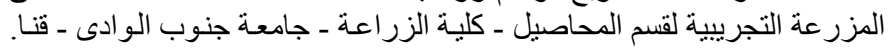

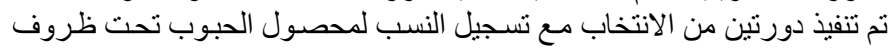

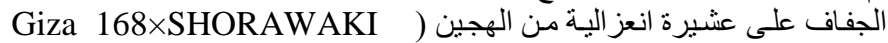

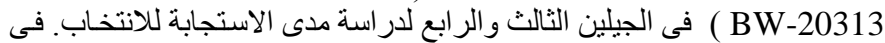

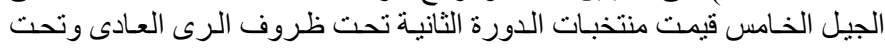

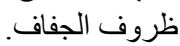

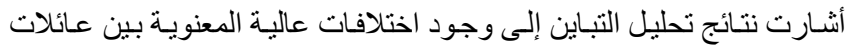

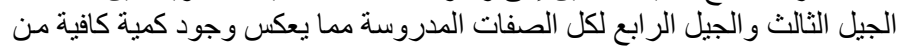

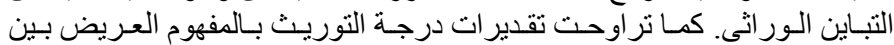

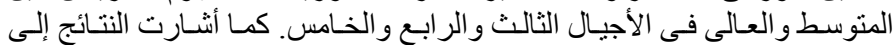

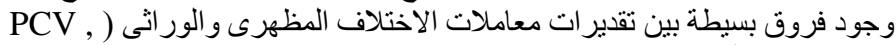
GCV

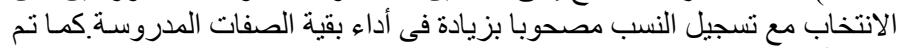

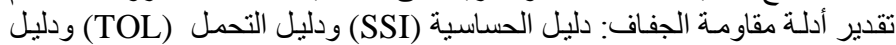

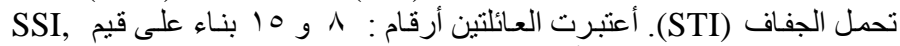

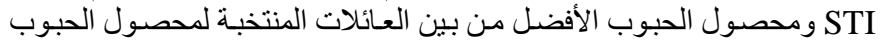
تحت ظروف الجفاف. 